\section{Publishing Ethics}

SIR,- - The suggestion that authors should regard it as unethical to negotiate with more than one book publisher (Nature, 234, 367; 1971) is curious. Several unethical practices by major publishers overshadow the sort of callousness mentioned. Baumol and Heim (Amer. Assoc. Univ. Prof. Bull., 53, 30 ; 1967) give some examples as well as advice (see also ibid., 53, 275 ; and 55, 121).

In addition to the usual risks an author runs of incompetent or biased referees (one recent paper of mine was rejected by a journal because two referees thought reduction required necessary as well as sufficient conditions), book publishers present other hazards, even legitimate ones. Contract requirements differ and cannot usually be known in advance. Acceptance or rejection of a manuscript may depend crucially on factors other than its quality. Delay in publication is a major variable. And so on.

An appropriate procedure is to send an abstract and chapter titles to several publishers to see if they are interested, assuming quality of the full manuscript to be adequate. Each publisher should know it is not the only one approached.
Much can be done at this stage with relatively little bother, and full negotiations can then be pursued with the most promising publisher.

\section{Yours faithfully, \\ Leigh Van Valen}

Committee on Evolutionary Biology,

University of Chicago,

5734 Ellis Avenue,

Chicago, Illinois 60637

\section{Case against Hysteria}

SIR,--Whilst always treating the utterances of prophets of doom with due caution, I must nevertheless take issue with your editorial "The Case against Hysteria" (Nature, 235, 63; 1972). The tone was complacent and patronizing (which helps nobody) and the content contains at least one point for rebuttal. For example, in the passage on power supply and oil resources, you state-and I agree-that nuclear power generation will become more competitive with (and, one assumes, will eventually replace) conventionally fuelled generation; but the point is that increasing supplies of power from whatever source will increase pollution, even if it is only thermal pollution. Furthermore, the case of nuclear power was a particularly bad one for you to quote as the longlived radioactive wastes represent a severe long term hazard. Fusion reactors which should produce no longlived radioactive waste are much further off in time.

It can be argued that all this is perfectly obvious, that science/technology will produce solutions to environmental problems and that I am suffering from what Sir Peter Medawar called a "failure of nerve". However, experience shows that the operating time scales of both industry and government are far too long even when confronted with the obvious, so you must forgive me if I begin to feel distinctly uncomfortable.

The scramble for limited resources may have disastrous results (Korea and tungsten is surely a good enough warning) and it is right and proper to be concerned, even though this concern takes the form of "mere speculation" as you put it. Incidentally, since when has "speculation" been dismissed as "mere"?

Yours faithfully,

BRYAN LEVENE

57A Burrard Road,

London NW6

\section{Announcements}

\section{University News}

Dr S. J. Goldsack has been appointed to the new Control Data chair of computing science in the Department of Computing and Control, Imperial College, University of London.

Professor Kenneth Simkiss, Queen Mary College, London, has been appointed professor of zoology in the University of Reading.

\section{Miscellaneous}

Sir Hugh Linstead, chairman of Macarthy's Pharmaceuticals Limited, has been awarded the charter gold medal of the Pharmaceutical Society of Great Britain, for his outstanding services in promoting the interests of pharmacy. The Society's charter silver medal has been awarded to Mr Cyril Turner.

The platinum medal of the Institute of Metals has been awarded to the Earl of Verulam, Delta Metal Group, for his services to the non-ferrous metal industries. The Institute has awarded the Rosenhain medal to Professor R. E. Smallman, University of Birmingham, the W. H. A. Robertson medal and premium to Mr D. Green, UKAEA Reactor Fuel Element Laboratories, and the W. J.
Kroll medal and prize to Dr $\boldsymbol{O}$. Kubaschewski, National Physical Laboratory. The British Committee of Award announces the following appointments to Harkness fellowships of the Commonwealth Fund: A. H. Curran, St John's College, Cambridge, chemistry; I. S. Duff, New College, Oxford, computer science; P. Lennie, King's College, Cambridge, neurophysiology; I. R. McDougall, Glasgow, nuclear medicine; H. Pearson, University College, London, chemistry; R. B. Vinter, St John's College, Cambridge, electrical engineering.

\section{International Meetings}

March 1, Aspects of Quality Control during Manufacturing, Hoddesdon (Society for Analytical Chemistry, 9-10 Savile Row, London W1X 1AF).

March 7, The Role of Metals in Biological Systems, excluding Enzymes, London (P. Woodward, School of Chemistry, The University, Bristol BS8 1TS).

March 8, Adhesives, Birmingham (The Secretary, Institution of the Rubber Industry, 4 Kensington Palace Gardens, London W8 4QR).

March 8, Is There a Need for Impurity Standards in Organic Analysis?, London (Society for Analytical Chemistry, 9-10 Savile Row, London W1X 1AF).

March 8, Present Trends in Analytical
Research, York (Society for Analytical Chemistry, 9-10 Savile .Row, London W1X 1AF).

March 8-9, Climatic Resources and Economic Activity, Aberystwyth (J. A. Taylor, Department of Geography, University College of Wales, Llandinam Building, Penglais, Aberystwyth, Cardiganshire).

March 8-10, Molecular Studies in Viral Neoplasia, Houston (Symposium Registration, University of Texas at Houston, M. D. Anderson Hospital and Tumor Institute, Houston, Texas 77025, USA).

March 9, Chemical Engineering Developments in Mineral Processing, London (J. R. Theobald, Atomic Weapons Research Establishment, Building A.75, Aldermaston, Reading RG7 4PR).

March 13-16, Physics Exhibition, London (Institute of Physics, 47 Belgrave Square, London SW1X 8QX).

March 14, Survival and the Industrial Librarian, London (Miss P. Barrie, IBM (UK Laboratories) Ltd, Hursley Park, Winchester, Hampshire).

March 16, Developing and Marketing a New Food Product, London (Institute of Food Technologists, c/o Cotswold House, Westhorpe, Sibbertoft, Leicester LE16 9UL).

March 16, Carbon in Effluents, Nottingham (Society for Analytical Chemistry, 9-10 Savile Row, London W1X 1AF). 